\title{
How to Promote the New Energy Vehicles under China's “Internet plus" Initiative: A Review
}

\author{
Fan Yang*, Pinjie Xie, Bowen Xiang \\ College of Economics and Management, Shanghai University of Electric Power, Shanghai, China \\ Email: ^shiep_110@sina.com, yjzxpj@163.com,15000608319@163.com
}

How to cite this paper: Yang, F., Xie, P.J. and Xiang, B.W. (2020) How to Promote the New Energy Vehicles under China's "Internet plus" Initiative: A Review. Energy and Power Engineering, 12, 154-181. https://doi.org/10.4236/epe.2020.125012

Received: April 30, 2020

Accepted: May 18, 2020

Published: May 21, 2020

Copyright $\odot 2020$ by author(s) and Scientific Research Publishing Inc. This work is licensed under the Creative Commons Attribution International License (CC BY 4.0).

http://creativecommons.org/licenses/by/4.0/

\section{(c) (i) Open Access}

\begin{abstract}
Under the background of the rapid development of the Internet, new energy vehicles (NEVs) have ushered in an excellent development opportunity. With the subsidy policy exiting, new energy vehicles are facing unprecedented challenges. One purpose of stimulating the NEVs through "Internet plus" initiative is to promote diversification of vehicle energy systems and advance industrial upgrading and transformation. On the premise of "Internet plus", the paper analyses the obstacles and opportunities of new energy vehicles from four aspects, and proposes a promoting development model which includes management mode and profit mode, and constructs a promoting development framework which is about three stages of new energy vehicles. Finally, from the perspective of the new energy vehicle charging, the paper puts forward some policy advice to promote industrialization and popularization of new energy vehicles in China.
\end{abstract}

\section{Keywords}

New Energy Vehicle, Charging Pile, The Internet plus, Development Model

\section{Introduction}

\subsection{Background and Trend}

In terms of the development trend of new energy vehicles (NEVs), the control technology of motor drive is based on a new generation of power electronic device, which will achieve its industrialization by 2020 . In the next ten years, the technology of intelligent electric vehicles will likely change the overall pattern of the vehicle industry. Advanced technologies of fuel cell vehicles have begun to penetrate the market [1]. 
In 2015, the annual sales of NEVs in the world reached 6 million, and the vehicle ownership amounted to more than 13 million, then the industry entered the stage of industrialization. China has surpassed the United States as the world's largest new energy vehicle producer and market with a sales volume of 3.79 million, accounting for about $64 \%$ of the world's total. In 2018, the sales of global new energy vehicles still increased to $1,256,000$, a year-on-year growth of $61.7 \%$. As shown in Table 1 , many countries make some plans to promote the development of new energy vehicles.

\subsection{Trend of Internet plus NEVs in China}

The production and sales of NEVs in China are going up. In 2018, new energy vehicle production and sales amounted to $1,270,000$ and 1,256,000, respectively, and the year-on-year growth reached $59.9 \%$ and $61.7 \%$, respectively [2]. By the end of 2018, 330 thousand public charging piles were built, 6 times as many as in 2015. Beijing, Shanghai, Shenzhen and other cities have built large-scale charging service networks. In 2020, the building of charging piles will be further accelerated. The concept "vehicles and charging piles promoting each other" acted as the core of the new energy vehicle development [3]. As shown in Table 2, the trend of the Internet plus new energy vehicles is analyzed from five aspects, which are Mechanism, Infrastructure, Technology, Industry and Market [4].

According to the definition by the relevant announcement from the State Ministry of Industry and Information, new energy vehicles are referred to the vehicles using non-conventional fuels as power source or conventional vehicles with new driving device, on the strength of which the advanced theories, new technologies and new structure designs can be applied to the vehicles [5]. NEVs, including pure electric vehicles (PEVs), fuel cell vehicles (FCVs), hybrid electric vehicles (HEVs), plug-in hybrid electric vehicles (PHEVs), hydrogen-powered vehicles (HPVs) and solar vehicles, etc., are equipped with more than two kinds of power devices: battery, fuel cell, solar cell and turbine locomotive.

On July 23, 2014, Shanghai Automotive Industry Corp (SAIC) signed the strategic cooperation agreement on "Internet vehicles" with Alibaba Corporation, officially beginning the strategic cooperation on the Internet and the vehicle

Table 1. Promotion plan for the new energy vehicles in the world.

\begin{tabular}{cl} 
Country & The promotion plan for the NEVs \\
\hline China & By 2020, the total production and sales will reach 5 million. \\
South Korea & By 2020, the number of NEVs will maintain more than 1 million. \\
Bermany & $\begin{array}{l}\text { By 2020, the number of electric and hybrid vehicles on the road will reach } 1 \\
\text { million, and will reach at least } 6 \text { million by } 2030 .\end{array}$ \\
Bapan & $\begin{array}{l}\text { By 2020, a new generation of vehicles will account for } 50 \% \text { of new vehicles sales, } \\
\text { Bith a total capacity of } 13.5 \text { million; }\end{array}$ \\
France & By 2030, a new generation of vehicles will account for $70 \%$ of new vehicles sales. \\
Netherlands & By 2025, there will be 1 million electric vehicles on the road.
\end{tabular}


Table 2. The trend of the Internet plus new energy vehicles in China.

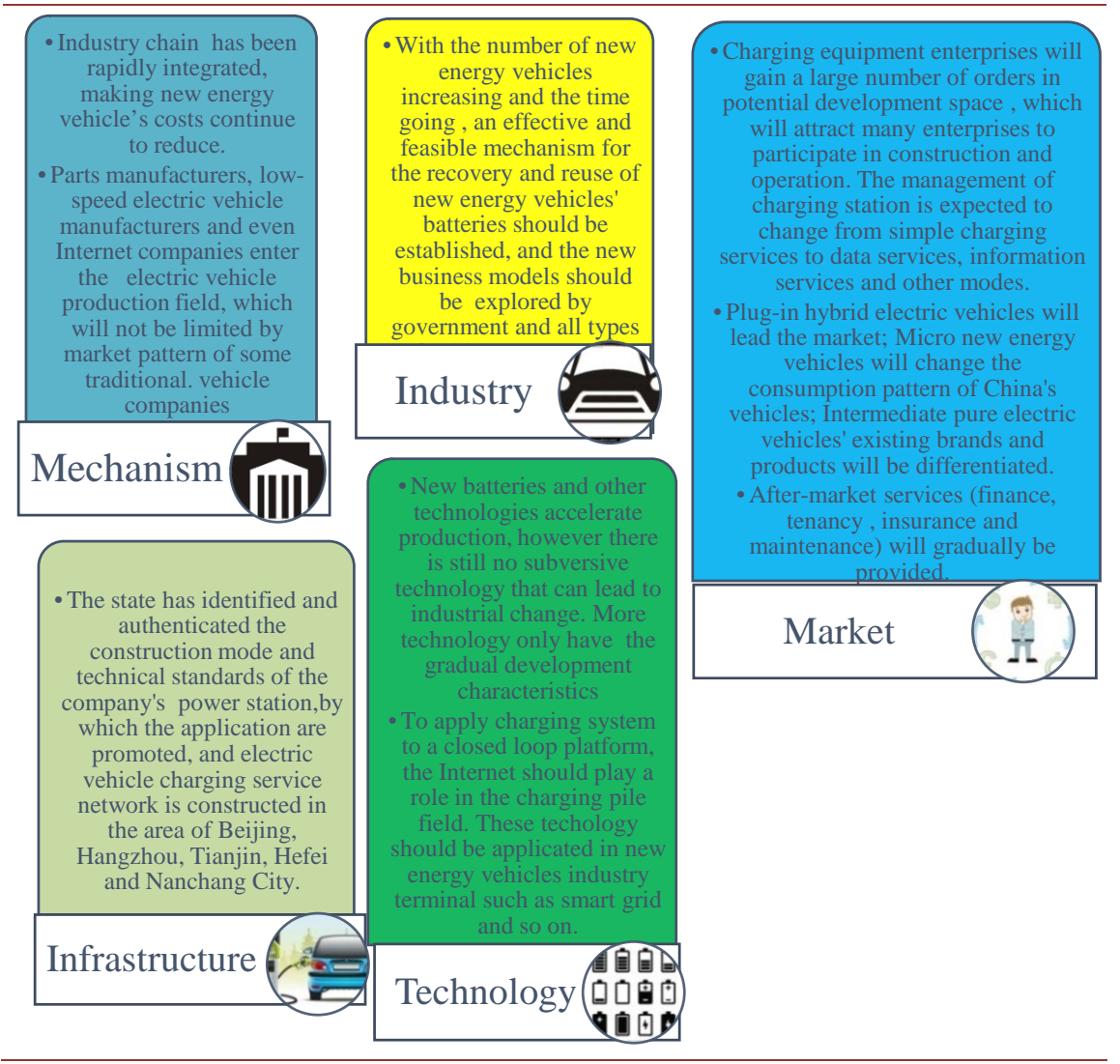

industry, and the term "Internet vehicle" was put forward officially. Then the two enterprises will start to cooperate in the Internet, vehicles and related fields [6].

According to the description of the "Internet vehicle" of SAIC and Alibaba Corporation, the "Internet vehicle" is a vehicle that entirely is integrated with the operating system, big data, cloud computing, communications, navigation system and entertainment to promote the end-user experience. Behind its hardware, there is an Internet vehicle system which is more open and integrated with Internet technology and big data, and the ecosystem is focused on users' daily life by coordinating the online and offline resources to provide users with smart travel services [7].

\section{Status Quo}

\subsection{Policy Environment}

At the third session of the twelfth National People's Congress in 2015, Premier Li Keqiang first put forward the "Internet plus" action plan in the government work report, to enhance the integration of Mobile Internet, Cloud Computing, Big Data, Internet of Things and modern manufacturing industry. The development of e-commerce, Industrial Internet and Internet Financial should be promoted, and Internet enterprises should be guided to expand the international 
market. Therefore, under the background of this, "Internet plus new energy vehicles" becomes the combination of the Internet and the real economy, playing an important role in promoting the transformation of new energy vehicles industry.

As shown in Table 3, NEVs have been adopted as China's national strategy, and the country's incentive policies for NEVs are gradually put forward. These policies are aimed to eliminate the possible institutional, sectional interests, and social barriers to the application of NEVs, and tend to focus more on ambitious enterprises and other areas of dynamic capital [8].

In 2016, the media unveiled several subsidy cheating scandals with some policies forced to be adjusted to meet the needs of the development of the industry and avoid loopholes. On January 1, 2017, the Ministry of Industry and Information officially promulgated the "Notice on Adjusting the Subsidy Policy for Popularization and Application of $N E V s$ ". Despite the tighter policy and reduction of subsidies which cause the new energy vehicle industry to a real test of marketing competition, it will also gradually lead the sound development of the new energy vehicle industry [9].

\subsection{Market Situation}

\subsubsection{Production and Sales}

With support from the national policies, the production and sales of NEVs in China are increasing year by year. As shown in Figure 1, since 2005, the sales of NEVs in China have shown an apparent upward trend. The average annual growth rate is over $30 \%$, which indicates that it has a bright future in promoting the use of NEVs. According to the Automobile Association statistics, in 2018,

Table 3. China's policy environment of new energy vehicles.

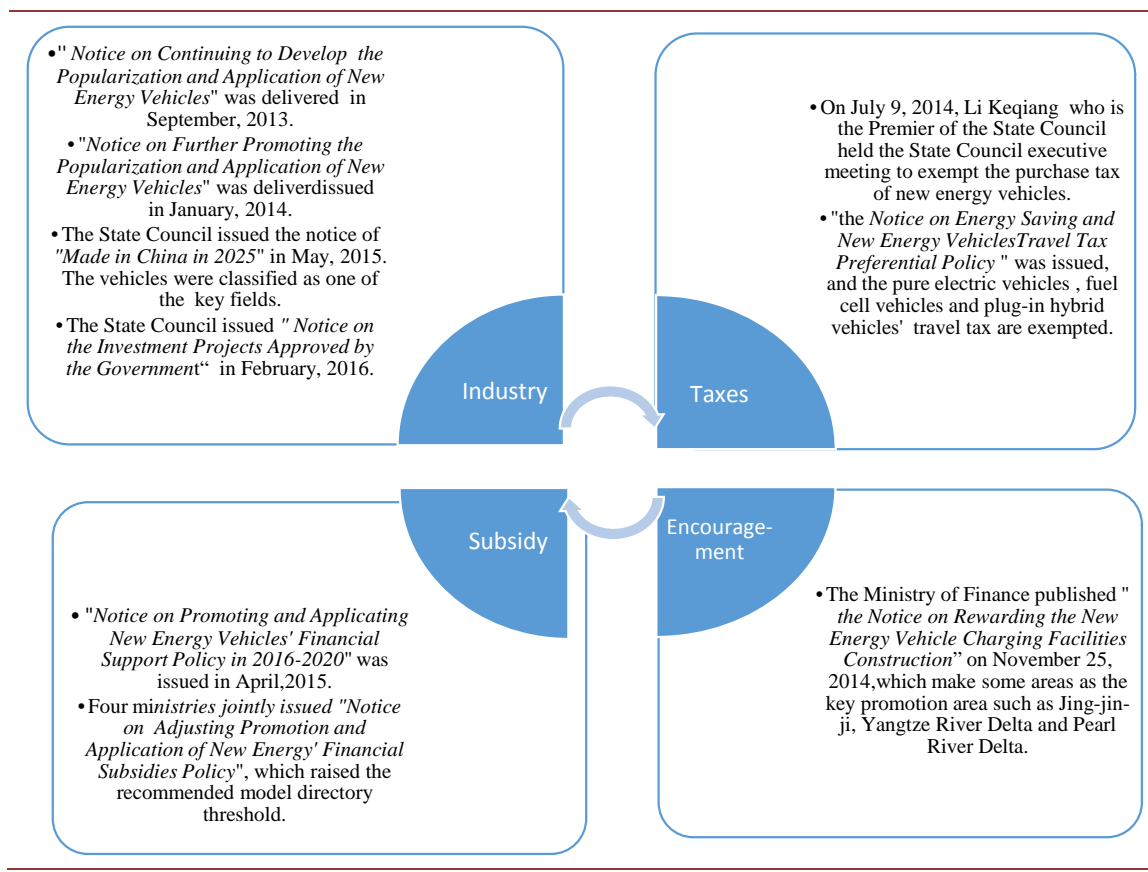




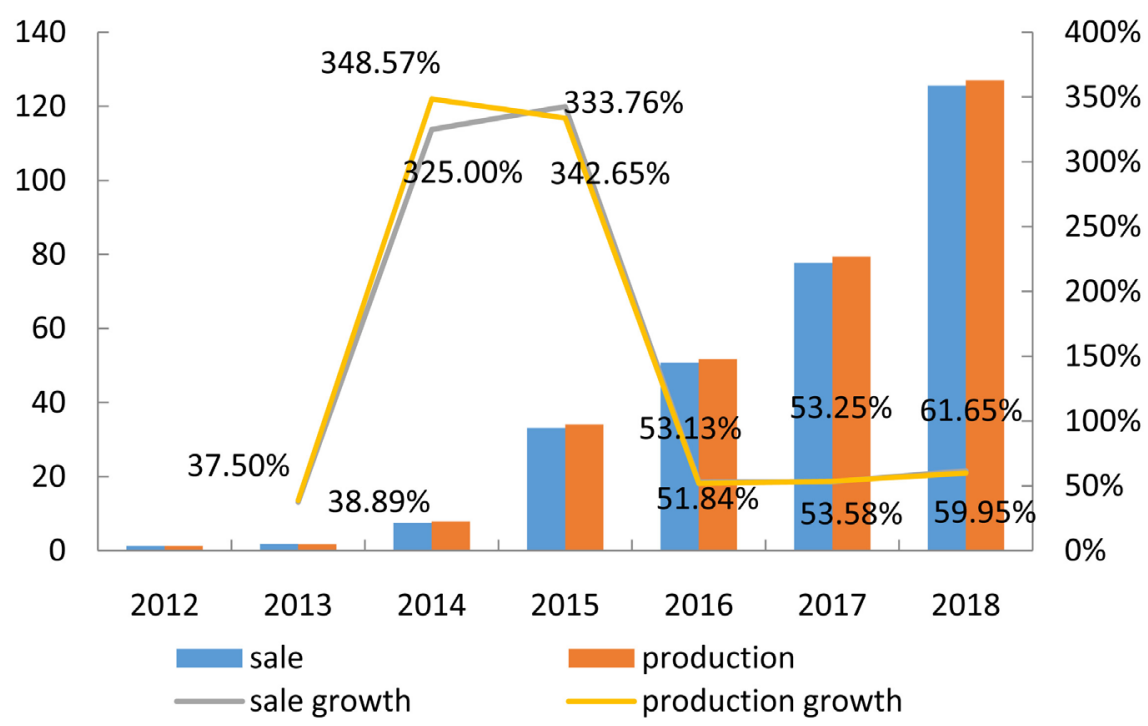

Figure 1. China's production and sales and growth of new energy vehicles.

the production and sales volume of NEVs reached 1,270,000 and 1,256,000 with a growth rate of more than $61.65 \%$ and $59.95 \%$ respectively (Figure 2). The production and sales volume of energy vehicles (EVs) reached 986,000 and 984,000 with growth rates of more than $47.9 \%$ and $50.8 \%$ respectively. Hence, the EVs have always dominated China's new energy vehicle market. The production and sales volume of PHEVs reached 283,000 and 271,000 with growth rates of $122 \%$ and $118 \%$ respectively.

Before 2017, sales were gratifying by massive subsidies and limited licensing policies in some areas. However, with the subsidies falling, production and sales went into a temporary slump, then they gradually stabilized. Also, these emerging business models, such as Time-sharing leasing and Car-sharing, have become the highlight of stimulating the potential of NEVs, and are gradually forming an industry consensus.

Although the development of NEVs has broad prospects in China, it is still in its initial stage in the current market. Moreover, with the national Subsidy-cut policy introduced, NEVs industry will return to the market. By 2020, the subsidies will completely withdraw from the market. At the beginning of 2017, because of the policy of falling subsidies, the market of new energy vehicle was in a shortfall. However, the proportion of NEVs still occupies $50 \%$ of the world, which shows that NEVs are developing rapidly with government subsidies. With a substantial policy boost, in 2018, the sales in NEVs of China were 1,256,000, production and sales ranking first in the world two years; the total amount of promotion was more than 3 million, accounting for $50 \%$ of the global market [10].

\subsubsection{Geographical Distribution}

By 2018, the number of NEVs in China has exceeded 3 million, accounting for more than $50 \%$ of the global market, ranking first in the world [11]. 


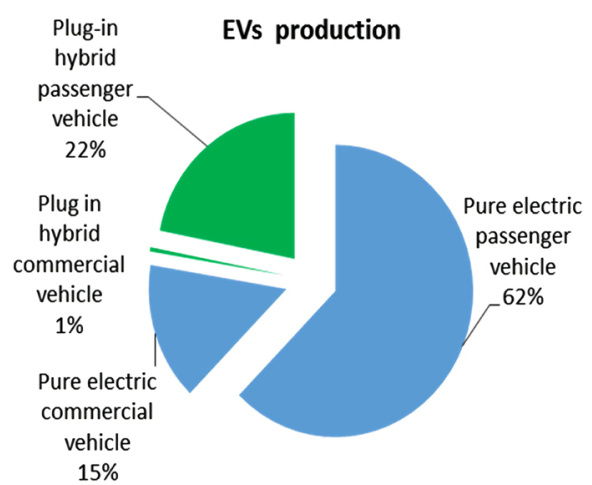

(a)

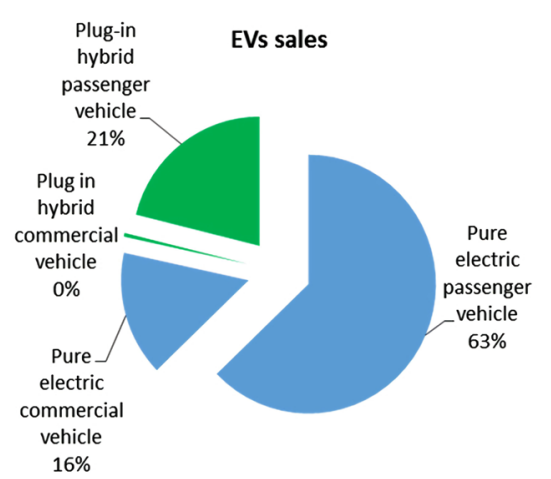

(b)

Figure 2. China's production and sales of NEVs in 2018. (a) NEVs production; (b) NEVs sales.

Shenzhen, Beijing, Shanghai and Hefei implement more ambitious policies for the promotion of NEVs, exceeding other provinces and cities. From the type of NEVs, China has been pushing for pure EVs and HVs over the past few years, while plug-in hybrids and fuel cell vehicles are limited in number. Among them, Shenzhen, Zhengzhou, Shenyang and other cities mainly promote hybrid cars; Beijing, Hefei, Guangxi, Qingdao and other cities give first place to promote PEVs.

\subsubsection{Market Situation of Sub-Industry (Table 4)}

\section{1) Power Battery}

The new energy vehicle power battery can be divided into battery and fuel cell, the battery is used in EVs, HEVs and PHEVs; fuel cell is used in FCVs (Table 5). According to statistics, China's actual battery capacity will be close to $100 \mathrm{GWh}$ by the end of 2016, but the actual demand is the only $20 \mathrm{GWh}$, so in 2016 there have been structural surplus phenomenon: new entrants or enterprises producing poor-quality products, as well as enterprises without standardized products will be seriously excessive, but the demand for high-quality battery products exceeds the supply [13].

Because of their significant differences in performance, material and cost, the future of different types of power batteries is different. At present, the most mature technology is nickel-hydrogen power battery, but lithium-ion batteries are the most successful in the commercial promotion, and fuel cells are widely regarded as a long-term goal [14]. Currently, the lithium battery is the fastest-growing category. Since 2012, the lithium battery industry has maintained its rapid growth and has accelerated the substitution of conventional batteries. Lithium batteries are expected to continue to grow at an average annual rate of nearly 25\%; at the same time, costs will continue to decline.

In recent years, the rapid development of new energy vehicle has increased the sales of domestic power battery, and industrial concentration has also been continuously improved. According to incomplete statistics, the total capacity of the industry has exceeded 120 million kilowatt-hours $(\mathrm{kWh})$. The future demand for 
Table 4. The order of investment of different products on the chain of NEVs [12].

\begin{tabular}{ccccc}
\hline Order & Sub industry & Trade barrier & Industry transfer space & Demand elasticity \\
\hline $\mathbf{1}$ & Electrolyte & High & Larger & High \\
$\mathbf{2}$ & Diaphragm & High & Large & High \\
$\mathbf{3}$ & Vehicle & Higher & Medium & Less \\
$\mathbf{4}$ & Motor control & Higher & Medium & High \\
$\mathbf{5}$ & Lithium resources & Lower & Medium & Less \\
$\mathbf{6}$ & Charging pile & Low & Large & High \\
\hline
\end{tabular}

Data source: Huatai Securities Research Institute.

Table 5. Comparison of battery and fuel cell characteristics [14].

Battery

- It is the only power source of the drive system in pure electric vehicles, mainly including nickel cadmium, nickel hydrogen and lithium ion batteries. At present, the lithium ion battery is in a stage of rapid development, and it is used in many new energy vehicle, such as the Nissan Leaf, TOYOTA Prius plug-in, Tesla Model S, general Volt Focus, Ford EV and BMW I3 and so on. In addition, lithium resources are more abundant, and the price is not expensive, it is said that lithium-ion batteries are currently the most popular in market power battery.

Fuel cell characteristics

- It is a device in which the chemical energy of fuel and oxidant is changed directly into electric energy through the reaction of electrodes. The fuel cell does not need charging, and has the advantages of high specific energy, long service life, less maintenance work and continuous power supply. In addition, fuel cell vehicles can achieve over the same mileage as fuel vehicles. According to the electrolyte, fuel cells can be divided into five types: alkaline fuel cells, phosphoric acid fuel cells, proton exchange membrane fuel cells, dissolved carbonate fuel cells and solid oxide fuel cells. At present, proton exchange membrane fuel cell (PEMFC) is widely used in fuel cell vehicles. It is the most competitive battery type in the future of new energy vehicles and power batteries.

China's power battery market is about 80 million $\mathrm{kWh}$. Further, considering the expansion of power battery capacity, the domestic battery capacity will be severely excessive in recent years, and the trend of market differentiation will become more and more evident.

The rapid development of the new energy vehicle industry will have a significant driving effect on the battery enterprises, lithium battery materials and resources matched enterprises [14]. In the manufacturing process, batteries, motors and electric control belong to the core system of EVs. At present, the vast majority of the domestic battery and motor in electric vehicle enterprises depend on outsourcing. Because the electronic control system is related to vehicle control, it is usually researched independently or developed jointly [15] [16].

\section{2) Charging Pile}

In 2018, China made great progress in charging infrastructure construction. The number of public charging piles has exceeded 330 thousand, and the proportion of charging piles for private passenger vehicles has increased to more than $85 \%$. Intercity-Express stations have been used in $20,000 \mathrm{~km}$ of express- 
ways, with an average distance of $48.6 \mathrm{~km}$ between stations.

Even if charging infrastructure has made substantial progress in 2018, and at the same time, the number of new energy vehicle market holdings exceeded 100 thousand in China and charging infrastructure is still relatively backward. Because there are some industry problems such as the scarcity of public charging piles, long queuing time and so far, they cause difficulties in charging in the entire electric vehicle charging industry [17].

\section{Internality Analysis: Obstacles and Threats}

The popularization of NEVs is still limited by many factors, such as the short battery lifetime, inconvenient charging, etc. The actual value of the NEVs for users is not much bigger than the ordinary ones, and the government subsidies act only as a stopgap measure, which cannot completely solve the problems concerning NEVs promotion [18] (Figure 3).

\subsection{Fundamental Problem: Basic Facilities Are Far from Satisfactory}

At present, the number of charging piles in the city is still small, and here comes such problem as "electric vehicles without charging piles", which destroys the enthusiasm for buying a car and user experience. Charging pile construction in some areas is encounters interventions due to security issues, inadequate power supply facilities, the operation of residential power grids and other reasons. At the same time, the policy statements are vague when the private charging piles are under installation, which causes the negative situation of charging pile promotion. The following are the specific reasons for inadequate facilities (Figure 4).

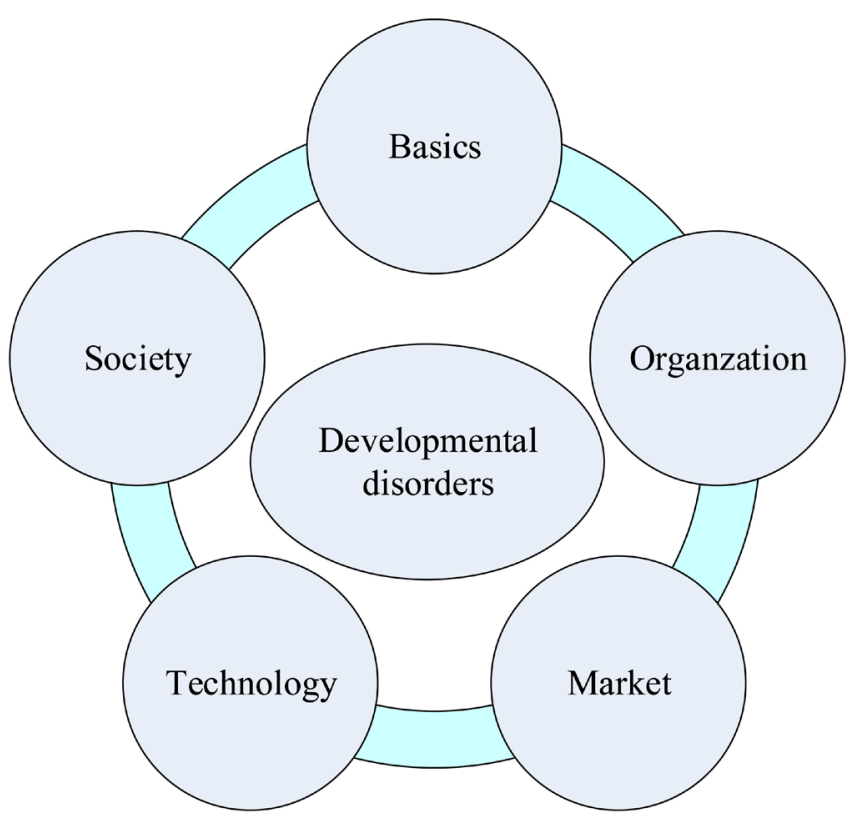

Figure 3. Development barriers of internet plus new energy vehicles. 


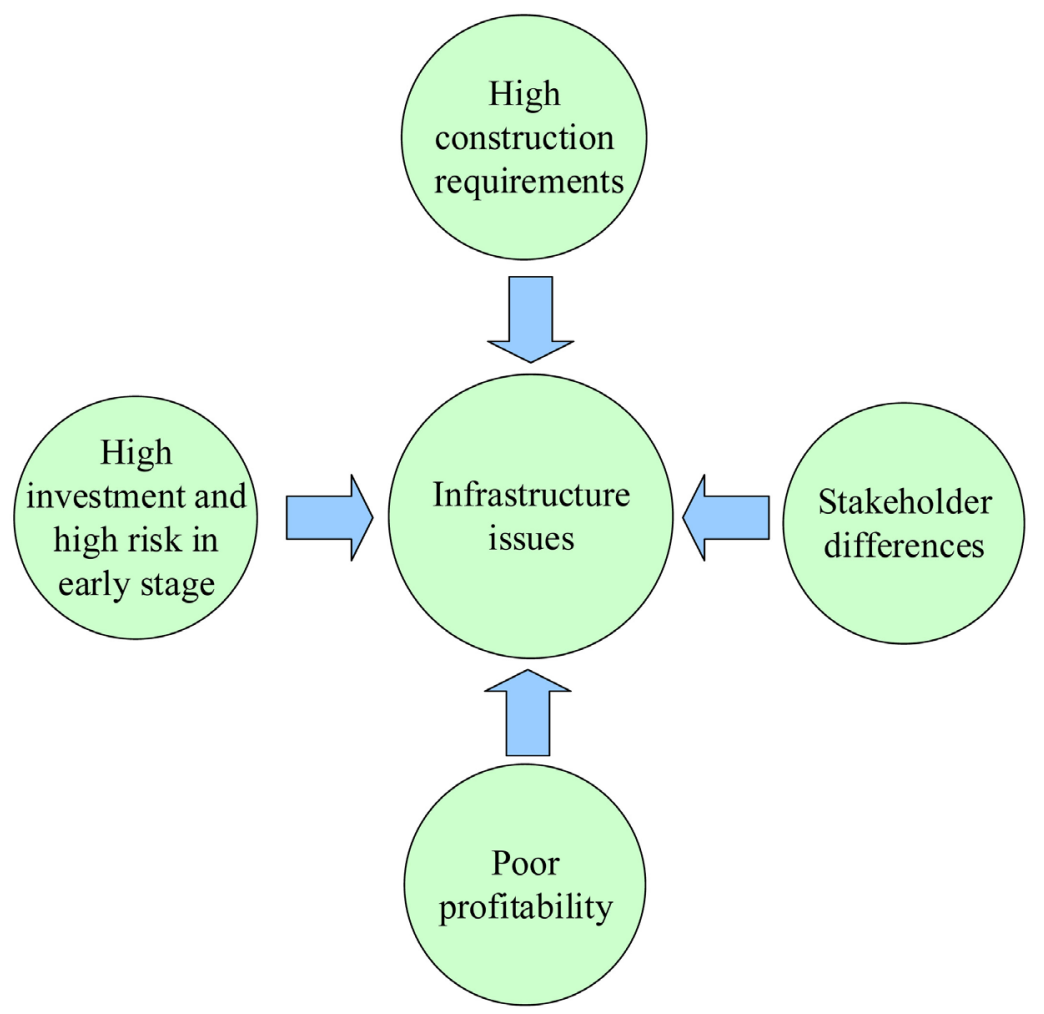

Figure 4. Reasons of basic facility problem during the development of new energy vehicles [19].

\subsubsection{High Requirement for Charging Facilities Construction}

A large amount of capital is required to be thrown into a large number of supporting facilities like charging stations when creating new energy automotive market. As the market in China is still at its initial stage, the technical standards of infrastructure services for NEVs are also lagging behind developed countries, and the related industries are backward and cannot form the corresponding industrial chain [20]. In addition to charging convenience and other factors, the demand for charging facilities is also high. Construction must meet the requirements of "Water supplies, electricity supplies, transportation infrastructure and well-chosen sites". The site selection is complicated to make, which poses great challenges to the construction of urban energy charging facilities [21]. In addition, charging facilities are a kind of large-scale electric power infrastructure, whose construction needs to take into consideration the impact on the power distribution system, such as power grid reconstruction, network loss and node voltage deviation, and the charging station is a kind of public transport services, and its status is equivalent to the traditional gas station [22]. Therefore, the construction of charging facilities needs to be properly considered and tries to minimize the adverse impact of the charging station in the distribution system, and it should premise itself based on reducing the harmful influence of charging station on the distribution system and tries to serve more vehicle users [23].

\subsubsection{Debates among Stakeholders}

State Grid, PetroChina, Sinopec, the automobile companies and battery enter- 
prises, which act as the main body related to the interests of electric charging facilities, disagree with electricity infrastructure construction and operation maintenance, reducing the enterprise's enthusiasm, hindering the battery enterprises in building electric charging facilities to a great extent. In terms of the charging mode, the power grid enterprises advocate using power exchange mode, while the car enterprises advocate charging mode. In terms of the construction standards, the charging mode is not adopted, and consumers want to use fast charging mode. In terms of the allocation of government subsidy funds, some problems with the differences between construction enterprises and operating companies should be solved urgently [24].

\subsubsection{Low Profitability}

The biggest problem that centralized charging stations have to face is low profitability, and the shortage of NEVs is the main factor that leads to decreasing returns of the charging stations the profit of the charging station. China's NEVs have developed rapidly in the past two years, but the overall quantity is still insufficient. According to the Chinese Automobile Industry Association data released in 2018, China sold 1256 thousand NEVs, and for two consecutive years its sales ranked first in the world, and the cumulative promotion amount has exceeded 3 million, which accounted for $50 \%$ of holdings charging facilities, but idle rate is still high, and investment is facing tremendous pressure [25]. Charging stations need to be equipped with a large number of charging duty personnel, resulting in higher operating costs, low efficiency and low profitability. From the actual situation, along with the Beijing-Shanghai high-speed charging station, 35 vehicles are stopping to charge every day during the Spring Festival, and during the rest of the time, the utilization ratio is lower. Sometimes there is no car stopping to charge, and charger maintenance and staff inputs are necessary.

Some problems also exist in the operation costs of public charging facilities. Since 2016, China has continuously introduced policies to promote charging facilities construction. Beijing, Shanghai, Guangzhou and other local governments have introduced policies to encourage charging facilities construction. However, some public charging facilities are maliciously damaged and abused, making the construction and operation costs of the public charging network much higher than those for personal use and exceptional facilities. Besides, EVs are mainly based on residential charging, which leads to low utilization of public charging network facilities.

\subsubsection{Big Investment and High Risk in Early Stage}

Whether the charging pile or the charging station, its initial investment ranges from tens of thousands to millions, and high construction costs cause the high risk of successful operation, even though the energy can be easily stored in energy storage stations of NEVs, there are still certain operation risks, because natural gas, hydrogen, dimethyl ether, ethanol and methanol are the fuels whose 
density is low and whose volume is large, and whether it is easy to compress and store is another problem [26].

\subsection{Market Issues: The Consumer Environment Is Immature}

At present, China's new energy vehicle market has not been established, and the development of industrialization and scale still need speeding up, and a pleasant consumer environment has not been shaped. Compared with European countries, there is a massive gap in the new energy vehicle market. The price of NEVs is too high to be accepted, and the consumer's awareness of environmental protection is not keen. Therefore, the further development of the new energy market is hindered [27]. According to the studies completed, it shows that only 4.3\% of users will choose NEVs, which directly reflects that the market demand for NEVs in China is relatively low. The acceptance of NEVs by the public in first-tier cities is generally more excellent than the second and third-tier cities' residents. According to some analyses, on the one hand, electric vehicles licensing conditions is not strict in the first-tier cities; on the other hand, the first-tier cities' charging piles, after-sales service and other supporting facilities construction are excellent [24].

The main reason why it is not well accepted is that the new energy vehicle performance still needs improving while the cost remains high, and the available infrastructure is still not able to play its expected role. First of all, about $70 \%$ of consumers expect that the car's driving range should be more than 200 kilometers, the price should be about 100 thousand RMB, and charging interval should be about 2 hours. With BYD Tang 100 as an example, its mileage is only 100 kilometers. However, the price is about 290 thousand RMB, and now the state subsidies abolished, and the price is higher than that most consumers expect. Secondly, at present, China's NEVs charging facilities are still in need of improvement, and the charging time is relatively long, which are the reasons why the majority of consumers consider not buying [28]. BYD Tang 100's charging interval is up to 6 or 7 hours, and most consumers cannot accept it. Therefore, to promote the development of NEVs industry, the government and vehicle enterprises need to work together to focus more attention on research and development and improve the performance of NEVs. At the same time, the price of NEVs should be brought down and the charging interval should be shortened gradually.

\subsection{Technical Problems: The Core Technology Needs to Be Improved}

The history of vehicle industry development is relatively short in China. Compared with European countries, the traditional technology of vehicle is still far behind, hurting the technology development of NEVs. China has a long way to go in the new energy vehicle core technology. For example, the research and development in critical components and public infrastructure needs speeding up, and it still relies on European procurement, and the localization rate is low. The 
main reason why the foundation of the NEVs industry is weak is that the funds and scientific research is weak and the development of the traditional vehicles industry is poorly developed.

There are some gaps between China's new energy vehicle enterprises and European countries' in technology, and many companies have blind faith in "mileage". Restricted by material and technology, the current mileage that batteries are able to cover is limited. To get better mileage, the car enterprises often increase the battery units, and to a certain extent, it increases the energy consumption and reduces available car use-space, leading to reduced comfort and safety [29].

Compared to multinational parts giants, China's enterprises are still not so competent in parts independent-manufacturing. The technology and associated equipment of battery diaphragms and other parts are fully mastered by the enterprises in developed countries [30]. At the same time, China still not have owned core technology in the vehicle's power train, and the domestic automobile manufacturers, including SAIC, vehicle models by cooperating with overseas giants and sharing intellectual property rights. The main components, such as motors and control systems, are mostly imported. For the domestic vehicle enterprises, if there is no improvement in domestic new energy vehicle parts system, the competitiveness of China's low-cost NEVs will not be enhanced easily [31].

\subsection{Social Issues: The Energy Structure Is Concerned}

From an environmental point of view, the biggest advantage of EVs is "zero emissions". However, it does not mean that it will not produce serious indirect pollution. At present, nearly $70 \%$ of China's electricity comes from coal-fired power generation; more than $20 \%$ is from hydropower, and about $10 \%$ is from nuclear power, wind power, gas power. In the United States, the proportion of gas power is more than $40 \%$, and coal-fired power generation is less than $30 \%$, while the remaining are nuclear power, wind power, hydropower and other clean energy. Despite China's efforts to promote clean energy construction, the rapid growth of energy demand will make the relatively cheap fossil power generation still dominant for a long time. According to the China Energy Development Plan issued by the National Energy Administration in June 2014, even in 2020 , the proportion of non-fossil fuels will reach $15 \%$ in ideal circumstances [32].

\section{Externality Analysis: Advantages and Opportunities}

\subsection{Political Aspect}

NEVs have been identified as China's national strategy, and policy will continue to be introduced. There are dozens of follow-up policies introduced. The traditional advantages of China's system are efficiency, and this efficiency will be fully embodied in the construction of new energy automotive industry [33]. The 
supporting policies to promote the development of NEVs industry have also been introduced, the National Development and Reform Commission issued "Guidelines for the Development of Electric Vehicle Charging Infrastructure (2015-2020)". By 2020, in order to meet the demand for the charging stations in terms of the 5 million EVs, the new centralized charging stations will reach more than 12,000 , and decentralized charging piles will reach more than 4,800,000. With the advancement of the policy, the problem of charging will no longer be the factors that restrict the development of the automobile industry (Figure 5).

\subsection{Industrial Aspect}

After several years of efforts, creative enterprises which even made or will gain global dominance, have made a decisive breakthrough in almost all the key "technical links" of the industrial chain. Chinese industrial system has made adequate technical preparation for the coming new energy tide [34].

The development of NEVs has driven investment in upstream and downstream industries and has been linked to key sectors, including basic materials, key components and manufacturing equipment. China has built four accumulation area of the power battery industry in the Pearl River Delta, Yangtze River Delta, Beijing-Tianjin-Hebei area and the Central Plains, becoming the world's largest producer of power batteries [35].

\subsection{Social Aspect}

Due to China's huge population, the market demand is also higher than that of other countries; consumers are beginning to lean towards NEVs because of high fuel prices. Besides, China's air pollution has been increasingly serious in recent

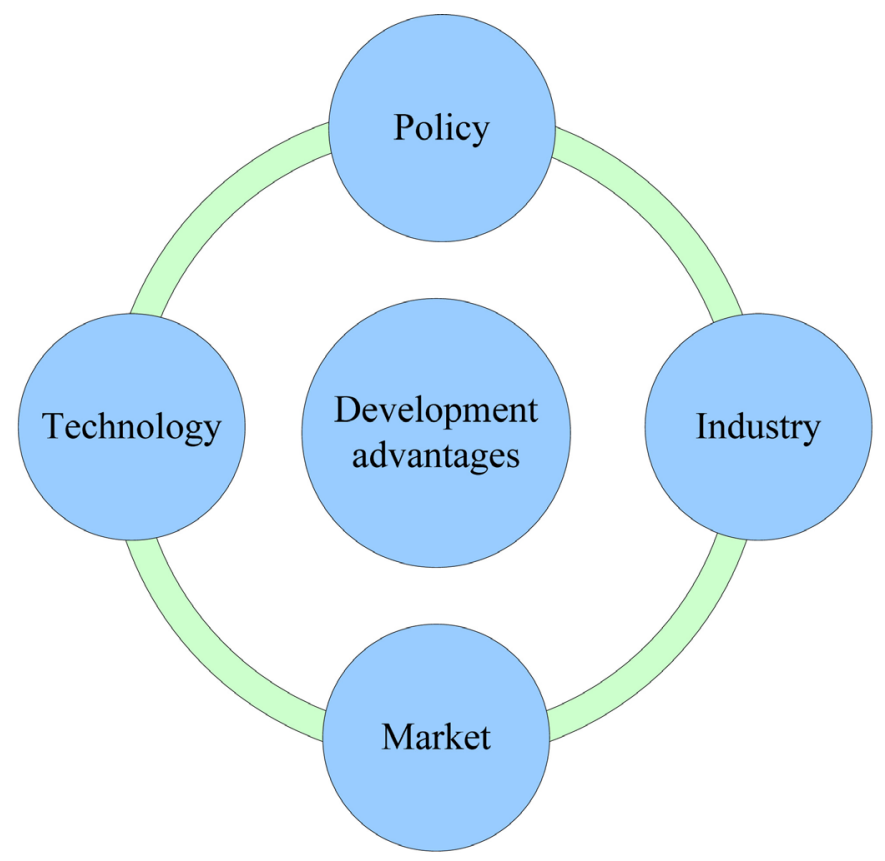

Figure 5. New energy vehicle development advantages. 
years, and consumers and the government prefer NEVs with low energy consumption [36]. With the promotion of NEVs in various regions, China's market, which is greatly affected by policy guidance, has a bright future.

\subsubsection{Population and Regions}

As a result of population advantages, China's auto market is huge, and it has great potential for development, and these advantages are also existing in the field of NEVs. The world's leading accounting firm issued the Blue Book of Chinese Vehicle Industry, the Blue Book shows that the number of China's NEVs reaches 330,000 in 2015, while the global NEVs only reach 500,000, and China has a substantial proportion. According to the Blue Book forecast, by 2022, China's annual output of NEVs will reach about 1,850,000. From 2015 to 2022 , the compound annual growth rate is $28 \%$. However, China's NEVs exist in the low-end car. In terms of power, endurance and comfort, many vehicles fail to meet the requirements [37].

\subsubsection{Energy and Environment [38]}

Excessive fuel prices and serious haze pollution are two of the many factors that accelerate the rapid development of NEVs [39]. NEVs play a great practical role in reducing vehicle emission pollution. NEVs with low fuel consumption provide an important way to alleviate the increasingly serious haze pollution [40].

\subsection{Technological Aspect}

The core technologies of EVs include motor, electronic control and battery. The motor system and the motor control system are becoming mature gradually, and the battery management system (BMS) has been made a breakthrough. The material of the battery has been made great breakthroughs in an all-round way completely, and it has subverted the monopoly pattern of Japanese enterprises. Several new energy vehicles manufacturers represented by BYD and JAC, more than 10,000 vehicles in the society have operated safely over tens of millions of kilometers. The motor and electronic control performance has been proven to be mature, fully equipped with the industrial pattern. The safety and service life of lithium batteries have also been up to the design standards. The core material technology in a lithium battery is made a breakthrough, and China's lithium battery is subverting the monopoly of Japanese enterprises and establishes their dominant position [12].

\section{Design of Promoting a Development Model}

\subsection{Business Model}

How to optimize the business model for china's NEVs? The paper focus on the two perspectives: profit mode and management mode as shown Figure 6.

\subsubsection{Profit Mode [3] (Figure 7)}

\section{1) Short-term: low cost and service charge}

The National Development and Reform Commission (NDRC) issued the "Notice on Issues Related to Electric Vehicle Pricing Policy" on July 30, 2014, 


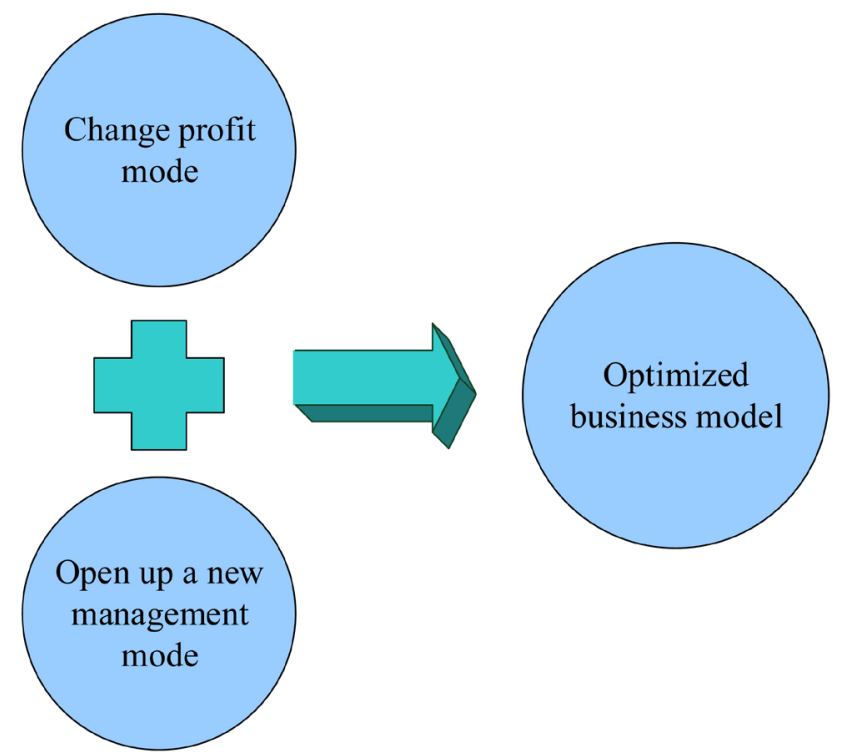

Figure 6. How to optimize business model of Internet plus new energy vehicles in China [41].

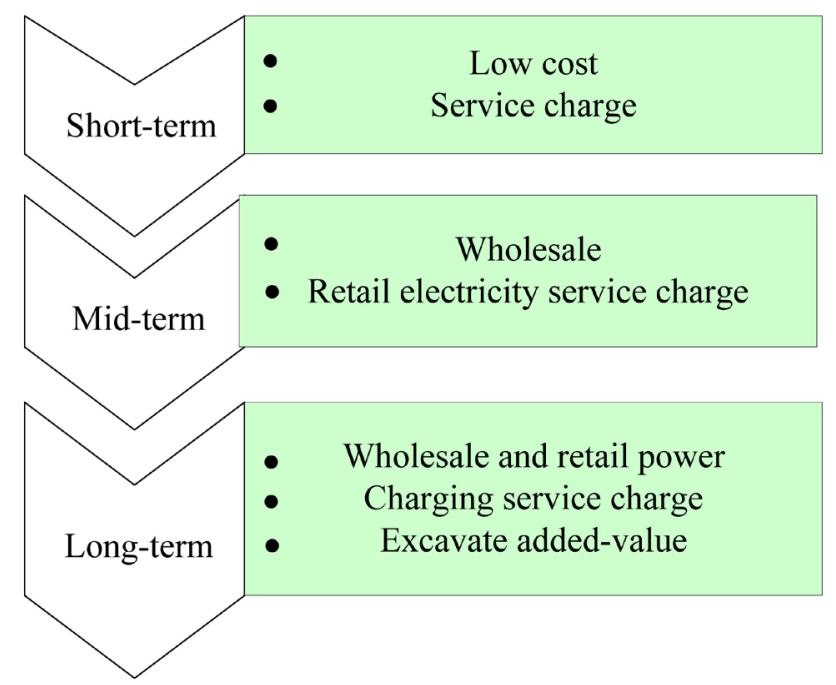

Figure 7. Profit model idea of internet + new energy vehicles on each stage [42].

based on which some operational models may be able to be established for the charging facilities. By the policy given above, charging station operators charge users for electricity and service, and the electric bills are based on electricity price set by the state (large industrial electricity price). As electricity price controls are still not lifted, the profit mainly depends on the service charge. In the early days, service charges initially followed the guidance prices of local governments, and gradually were determined by the market in next days. The local government decided to levy service charges in accordance with the principle of "Giving different and preferential treatment". At the same time, operating costs affect profitability. For charging stations, the charging process takes at least half an hour, and the waiting area must be set up. Therefore, compared with the traditional gas station, more area for the charging station should be covered, and 
the cost of land is very high. According to the "Notice", before 2020, the approach should be taken by governments to reduce operating costs, such as financial subsidies and free allocation of construction sites for charging facilities.

2) Mid-term: wholesale and retail electricity service charge plus charging service charges

There are inflexible rules on the formulation of charging a service charge. To promote NEVs vigorously, new energy vehicle enterprises must ensure that EVs' usage cost was significantly lower than that of fuel (or gas) vehicle. A high charging service charge will dampen the customers' enthusiasm for purchase and will also harm the charging infrastructure industry. More importantly, with more and more capital inflowing and price competition becoming fiercer, service charges will be reduced. Therefore, the initial charging service charge can be a major source of revenue, but it is not sustainable in the long term.

The service charges model is only suitable for the initial industry initial period. Considering that power market reform lifts control over retail electricity market if charging station operators apply for sale license, they are expected to develop new profit model. After retail electricity market was established, charging station operators make a purchase of electricity at wholesale prices and sell at retail prices, and hence the spread of wholesale and retail can become a meaningful way to generate profit. The more price margin of wholesale and retail is, the shorter the payback period becomes.

3) Long-term: Wholesale and retail electric and charging service charge plus determine the added value

Because the charging pile construction is affected by land availability and policies, the recycling cost lifetime will be extended. It means that private enterprises will experience the situation that the investment is long-term and the returns are slow, and the massive asset mode is challenging to maintain. Now all enterprises are investing in electricity construction, and investment risk increases. How to do an excellent job in charging pile value-added services? It will also determine the development prospects of charging enterprises.

The charging station is different from the traditional gas station, and the former provides charging service with more extended time, and high value-added services can be offered at this time. The electric vehicle charging piles can be made as to the center of this area where convenience stores are open, logistics transfer stations, car $4 \mathrm{~S}$ shops and other ancillary services. In the owner's charging time, retail and consumption business can be developed in-depth, improve the value-added services and tap new sources of income the source of income [43]. For example, during the charging period, the charging station can provide services such as automobile inspection, maintenance and so on, or get added-value by cooperating with the vehicles enterprises. For example, mobile reservation, online payment, station charging and maintenance process are achieved by developing APP. The entire industry chain of manufacturers, consumers and service providers are formed to create a comprehensive service ecosystem. Moreover, once the number of users is large, the operators of charging piles can charge ad- 
vertising fees and users surcharge by customizing charging scheme for customs, then profitability and user's stickiness are increasing. Finally, an "ecosystem" of self-growth will be formed.

In the big data era, the value of the data cannot be ignored. The charging piles can become an excellent carrier to collect the data of user's charging behavior. Then the necessary information of users can be obtained from the online APP. Next users' charging behavior and habits can be analyzed by massive data such as travel time, travel sites and charging time, and based on this; advertising can be put into a targeted consumer. At the same time, the scientific basis for the layout of charging piles can be provided [43]. From another perspective, when the electric vehicle charging station construction is completed, it will not only absorb power from the power system but also reverse electric energy into the grid by the electric vehicle batteries with energy storage characteristics, then considerable benefits will be obtained. The charging station can be used as electric vehicles agent. By optimizing the charging process, on the one hand, the negative influence caused by the large-scale electric vehicles accessing to electric power system can be weakened, such as network loss, voltage deviation. On the other hand, electric vehicles can participate in the power grid ancillary services through agents; then it can reduce reserves, peak load shifting and stabilize the volatility of renewable energy output. In terms of overall development situation, the profit model of charging station will gradually change from low-cost and single service to multiple-service mode. In addition to estimating the added value and creating a diversified profit model, the development of big data technology, the growth of NEVs and deepening of electricity market reform will become the key factors for the growth of the charging station.

\subsubsection{Management Mode (Figure 8)}

1) Government vehicle platform [44]

The innovative model of "the Internet plus travel" was introduced into government vehicles market to provide practical solutions for government vehicles reform in China. China's first platform for Internet official vehicles was put into operation in Jiangxi province. By the approach of "Internet plus", the distribution of resources can be more rational, and the data information can be developed and shared, at the same time, the cost can be controlled and transparent, solving two prominent problems of the official vehicles system, and it indicates the government's affirmative and supportive attitude towards the NEVs. To enhance public awareness of green-travel further, the civil servants should take the lead in demonstrating Green travel and play an exemplary role in popularizing the concept of energy conservation and environmental protection. The benefits of the cooperation between government and the Internet rental platform vehicles are to make full use of the platform of NEVs resources and to reduce the cost of conventional vehicles. Meanwhile, it is confirmed that the vehicle rental platform will practice green travel [45].

2) Interconnect sharing between pure electric vehicles [46] 


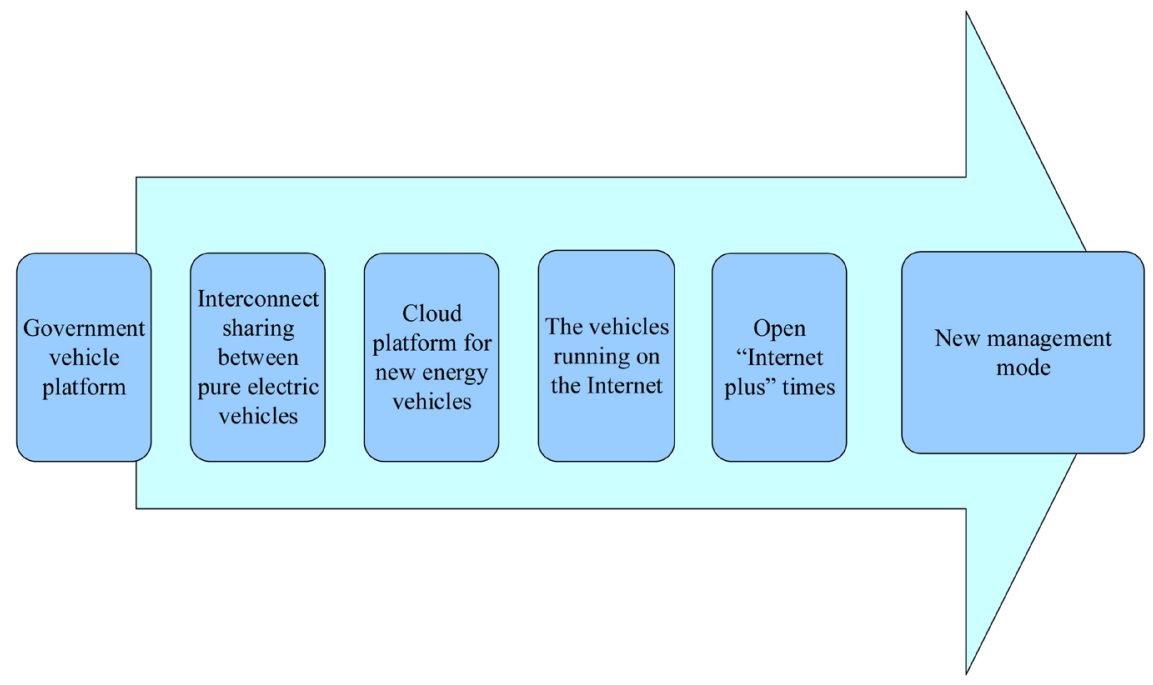

Figure 8. How to form new business model of new energy vehicle.

Intelligent shared electric vehicle based on the Internet, designing a better business model of promoting vehicle sharing, is aimed at sharing and being controlled by mobile Internet technology. " 100 million people share 10 million cars" is the goal, but everyone can drive a vehicle. To make more people enjoy travel convenience and save energy, the stock of vehicles resources should be shared [47]. The shared electric vehicle is an innovative exploration in the Internet vehicles and Internet travel, and it is also the best solution for the future urban intelligent transportation and further popularization of EVs. Through joining superior resources of NEVs, sharing platform and vehicle networking, a new vehicles operation model based on networking, mobile Internet and sharing economy can be explored and built. To make users experience convenient and intelligent travel based on the Internet, the Internet living circle and the vehicle demand in the "vehicle ecology" should be opened up. With the development of Internet technology, changes in consumer habits and the growing awareness of environmental protection, consumers' demands for vehicles will no longer be a simple mean of transport, and they are concerned more about a full set of travel solutions [48].

The platform also provides users with intelligent vehicles rental experience. Vehicles sharing innovation model will make China as the world's leader, improving the efficiency of resource utilization through sharing economy. For example, time-sharing lease is a kind of shared mode with car rental services; based on the charging piles, new energy vehicle sharing rental service outlets are built and charging network and time-sharing lease mode are established, realizing the sharing of resources, and expanding the coverage of the charging network and improving the service of public transportation [43].

\section{3) "Cloud platform" for new energy vehicles}

The charging facility is the entrance of the current and the data stream. The vehicles' travel data is obtained by the charging process, which offers an opportunity about added-value services such as vehicle sales, maintenance and so on. 
At the same time, the fusions of vehicle networking, pile networking and the Internet will form a cloud platform for NEVs, and in this platform, Internet business opportunities will be offered such as location-based services, payment services, Internet banking and so on. Additionally, the layout of the charging network adopts the method of combining points, lines and surfaces. Thereinto, the shops, transportation hub and tourist spots are the points; trunk roads are the lines where the charging station and charging terminal can be set; the $3 \mathrm{~km}$ to 5 $\mathrm{km}$ service radius is the surface where the lay charging station and charging terminal can be set in the public parking lot. The real-time location of each new energy vehicle can be displayed on an electronic map [49]. At the same time, the vehicle's driving direction, speed, power usage and battery temperature are monitored synchronously. Big data must be an essential part of the development in EVs in the future, and it is particularly important to build an "ecology", open and shared platform.

\section{4) "Vehicles running on the Internet"}

The vehicle enterprises which have the ability in developing independently make capital as a bond with IT enterprises which have the Internet content, services and "ecosphere", and integrate each resource with its advantages, and the vehicle enterprises should work together to build a "vehicles running on the Internet", promoting the development of Internet vehicles and the construction of operation platform. The capital platform will be opened in the future and will attract more Internet vehicles participants. The vehicle enterprises and IT enterprises will make full use of their strengths respectively, and become a pioneer in Internet vehicle technology, service operations, business models and user experience. The vehicle enterprises and IT enterprises should focus on user' demands to build a kind of life featuring "Internet vehicles". In addition to providing the vehicles with Internet resources such as communication, navigation, entertainment and so on, the IT enterprises can also offer online channels and financial support in the sales process of the vehicles, and carry out the added-value services that is "Use first and pay later".

\section{5) Open "Internet plus" times [50]}

From the perspective of third-party service providers, electric vehicle operation service providers contact the parts of the industry chain in China. By the model of "the APP of charging", "Intelligent city charging network" and "Operating system", the people, vehicles and piles are connected by using $\mathrm{O} 2 \mathrm{O}$ closed-loop, which are aimed at providing the user with the best experience, to solve the problems about "mileage anxiety" and charging which restrict the popularization and development of EVs. By the platform operations and data technology, charging piles will become an essential carrier of city location and entrance of vehicle networking, the network of position, traffic and vehicles can be promoted to construct intelligent transportation system, and form the Information Physics Department of the smart city system in future [29].

The large-scale NEVs network and charging network is the tendency in the city. The companies get access to the Internet ports of new energy vehicle service 
actively by constructing the "Internet plus new energy vehicle" charging station, and the service system of "Internet plus new energy vehicles" and "Internet plus charging" are formed gradually. By providing Internet services such as mobile intelligent charging management, remote monitoring, operation detection, diversity payment and so on, an $\mathrm{O} 2 \mathrm{O}$ service model which is "Mobile terminal APP plus cloud management system plus cloud platform data sharing plus offline charging equipment" is built, and an era of "Internet plus new energy vehicles" begins.

\subsection{Development Framework}

What is the development framework suitable for the layout of NEVs in the "Internet plus"? Charging piles are an indispensable link for NEVs to achieve "Internet plus", and the Vehicle networking is also an intelligent terminal that collects and detects all vehicle information. They play an important role in China's new energy vehicles. Thereby, the development framework of the Internet plus new energy vehicles is designed as shown Figure 9.

\subsubsection{Charging Pile}

Charging piles have been upgraded at the terminal of the entire Energy Internet. In the Energy Internet architecture, charging piles not only make energy revenues but also can retrieve energy data. In the Internet era, it has strong strategic significance in becoming a leader in the distribution of Energy Internet.

The "Notice on the Issuance of Energy-saving and NEVs Industry Development Plan (2012-2020)" shows that the quantity of the NEVs should reach 5 million in 2020 in China. To achieve the objective above, the number of the charging station should be 12,000 and the charging piles 4,500,000 [51]. That is to say, 50 - 100 charging piles will be installed per square kilometer in urban land. Also, the state has released the city charging piles facilities in China. Attracted by the market, many private enterprises enter this field and the market is expected to be

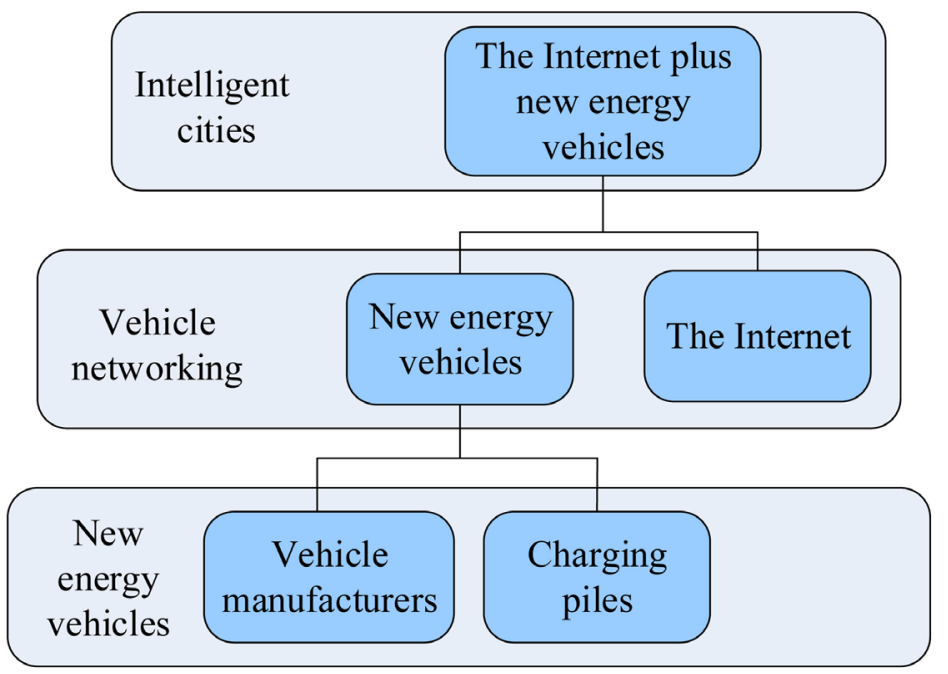

Figure 9. The development framework of Internet plus new energy vehicles. 
dominated by private enterprises. Local governments have introduced the policy for the development of charging piles, and several cities have also drawn up relevant construction plans (Table 6).

Charging piles can perform more smartly in data collecting, data buffer and remote management, and it is a field with a bright future in-vehicle networking. On the one hand, the power management departments need to collect all the data of the charging piles and provide data for the construction of a smart grid. On the other hand, the power management departments help to realize the remote management of charging piles. At the same time, charging piles play a role in data collection and data cache, which can upload the real-time data (charging pile's working state, the current-voltage and charging time) to the cloud, to support the dispatch center platform software for charging piles remote control, and fault information, security alerts can send feedback to the maintenance personnel. Charging piles are important sources of charging revenues, and they become the new entrance of vehicle networking. Charging piles can act as payment terminals, by which fields such as entertainment and applications can be opened up in the vehicles networking directly or indirectly. The core of the industry value chain will gradually move from hardware manufacturing to charging pile operations, and eventually, the charging piles will play a role in flow inlets of the Energy Internet architecture.

\subsubsection{Vehicle Networking}

NEVs will become another mobile terminal after smartphones, thus leading a revolution in the vehicle industry. It is the tendency that the Internet will integrate the vehicle industry, and the development of NEVs and smart vehicles promote Internet enterprises to enter the vehicle industry. On the premise of Internet companies having inherent advantages in data, communication and artificial intelligence, it is bound to get the qualification for pure electric vehicle manufacturing and draw up the blueprint for the smart vehicle industry to achieve the in-depth integration and development of new energy and intelligent vehicles [52].

With the development of wireless communication and the Internet, GPS and GIS (Geographic Information System) are used widely, and the Internet of Vehicles (IOV) emerged. The combination of GPS and wireless communication makes the vehicles as a mobile terminal, and hence the external environment and situation of vehicles can be transmitted in real-time. In the future, the terminal

Table 6. Charging construction plans on various regions of China in 2020.

\begin{tabular}{cc}
\hline City & The charging piles plan \\
\hline Beijing & Meet 600,000 electric vehicles' charging need \\
Shanghai & 211,000 \\
Chongqing & 150,000 \\
Tianjin & 92,000 \\
\hline
\end{tabular}


of IOV can change from single-mode to interactive mode, and the vehicular terminal has changed gradually from the traditional no-screen or simple scheduling screen to powerful scheduling screen. The ultimate goal is to establish a smart city system in the IOV industry. Through smart traffic, the problem of traffic jam and the development challenge of vehicles society can be solved. The three stages of the IOV development will be consist of interconnection between people and vehicles, between vehicles and vehicles and interconnection between vehicles and city, which shows us the future of "smart city system" is bright [53].

The IT companies are responsible for providing the open platform of the Internet, meanwhile, the high-tech enterprises are paying attention to the integration between high-tech mobile terminal and smart electric vehicles in design and manufacturing, and the high-tech enterprises are able to carry out multifaceted cooperation with vehicle manufacturers in the field of high-end vehicle marketing services [54]. Among partners, the advantage of high-end vehicles' marketing and services is significant when putting forward the business model of "Internet plus intelligent electric vehicles". At the same time, IT enterprises, high-tech enterprises and vehicle manufacturers have complementary advantages in their respective fields, to promote the innovation of business model and product jointly. In terms of improving the environmental ecological system and industrial chain, new intelligent electric vehicles should be researched and developed.

\section{Conclusions and Policy Suggestion}

\subsection{Conclusions}

In summary, here is the following conclusion:

Against the context of the "Internet plus" initiative, the paper looks forward to the prospects of NEVs, promoting its industrialization and popularization. The industrialization and prosperity in NEVs is to achieve the diversification of vehicle energy systems for automotive industry, but also a correct choice of transforming ideas, broadening horizons, and alleviate excess power in China. The development of NEVs should construct promoting development framework which is based on new management mode and profit mode through "Internet plus" initiative. As the important filed in the automotive industry, the development of NEVs is facing a major historical opportunity. It will play a vital role and exploit a unique advantage to form the new development framework, especially in the layout of charging piles, achieving the green transformation of China's energy. Therefore, NEVs in China must have a bright future.

\subsection{Policy Suggestion}

\subsubsection{Expansion of the Market Scale of Charging Piles}

1) Putting routine household charging as an energy supply system

At present, in China, the electric vehicle charging network consists of three parts: The first part is the household charging, which is generally installed by the pure electric vehicles' owners or vehicles enterprises. The second part is charging 
in destination, such as hotels, restaurants, office buildings, shopping malls, schools, community and so on, which is generally installed by Tesla and other car companies. Moreover, the third part is public charging stations, which mainly solve the charging problem of the trunk road network.

The mode of charging facility operation is supplemented by parking or family routine charging, which is the most likely charging operation model in china, as China's population density is not as low as the United States and Europe's and there are not many independent garages rebuilt with independent charging piles. The corresponding measurement equipment should be equipped and standards for fees should be set, and thus the popularization and application of electric vehicle infrastructure can be achieved

2) Improving charging service network construction

Charging infrastructure construction sites should be widely distributed and standard charging stations should be constructed in the residential and commercial center, and finally convenient charging network can cover the city, to meet the needs of electric vehicle users and to fulfill vehicles buyers' desire.

Energy distribution in the network should be reasonable. As a dynamic and controllable load, the electric vehicles can effectively alleviate the peak load of the power grid, and play a role in shaving peak and filling valley, which have a benefit on the economic operation of the overall power grid.

3) Constructing rational utilization of smart grid

A smart grid can improve the procedurally-interactive management of comprehensive power industry, which can carry on the generation, transportation, supply and use of power. A smart grid can not only meet customers' demand for electricity but also Hierarchical dispatching power grids, to meet the dual needs of users and power grids by smartness and informationization.

The stable operation and scheduling ability of urban power grid should be enhanced in the process of electric vehicles, and the uncontrollable risk of urban power grid should be prevented.

\subsubsection{Searching for the Better Charging Scheme}

There are two main charging modes: slow-charging and quick-charging.

1) Slow-charging usually adopts the mode of constant voltage or constant current, whose interval is usually $5-8 \mathrm{~h}$, and even up to $10-20 \mathrm{~h}$. The longer charging interval has higher requirements, and hence slow and conventional charging is only suitable for long-time parking occasions such as parking lot, family garage and other places, which is, at the same time, completed mainly by charging piles.

2) Quick-charging adopts strong-current, which will be mainly completed by the charging generator. Charging interval is usually $20 \mathrm{~min}-2 \mathrm{~h}$. This charging method makes the electric vehicles regain the electricity in a short time and solves the problem that the slow and regular charging interval are too long, and it is the key to promote the electric vehicle's performance. Quick-charging must have higher requirements for battery life, power distribution system and security 
issues, which will cause difficulties in the construction and operation of the charging station.

Costs and efficiencies should be balanced concerning different requirements while laying the charging circuit [55]. Along the highway, Quick-charging is more suitable. However, in private homes and public places in the city, Slow-charging should be chosen because of the lower cost. In public parking which is near the office, shopping malls, residential areas, enterprises and institutions, it is more suitable to adopt smart socket to charge. For plug-in hybrid power vehicles, as long as they are running in the city, they can be used as pure electric vehicles. Only in this way, can they exert an effect on energy-reservation, emission reduction and environmental protection. Therefore, the popularization of the smart socket in parking areas is the solution to the problem of charging. NEVs are genuinely available when charging piles are available everywhere.

\subsubsection{Charging Intelligence}

The users of the charging station are able to reduce cost and avoid the electricity stolen behaviors through smartcards, achieving the maximum utilization rate of charging station in the end; online charging station management service can track and report the data of energy consumption, greenhouse gas emissions and gasoline saving situation immediately, and the tabular can be shown on a daily, weekly or monthly, then the users can combine these data with other systems to analyze sustainable situation about development of enterprises. Online charging station management service provides full-time monitoring to ensure network services be provided and wireless software be updated; it also provides each electric vehicle user with a variety of services such as 24 hours hotline, charging notice, and history charging records; it also uses the practical meter to connect the smart grid system in the area to complete smart grid projects such as the corresponding demand side, real-time charging price estimation and monitoring.

\subsubsection{Construction of Charging Station}

State Grid Corporation of China (SGCC) determines the basic business model for Electric vehicles (EV) charging and battery swap stations as battery replacement being the principal means of powering vehicles, plug-in charging being supplemental and centralized charging as well as unified distribution [56]. That SGCC decides to update the simple charging station to the charging and battery swap stations greatly increased the target customer groups of the stations and enhanced its geographical adaptability. The battery replacement takes less time and can fully achieve mechanized automatic operation. The charging and battery swap station covers a relatively small area, which is very flexible in terms of layout in large cities where the land prices are so high. The construction of charging and battery swap stations will be more convenient if using the existing grid network [57]. In addition, centralized charging at night while power transmission by day can improve the distributional efficiency of power resources of SGCC [58]. At present, there is not a uniform battery standard, with each EV using battery from different manufacturers. If a unified battery standard can be 
set, the cheap and convenient battery replacement model will stimulate the rapid development of the EV market and will greatly boost the market growth of power battery.

\section{Acknowledgements}

This paper is supported by Funds for the National Natural Science Foundation of China Youth Project (Grant No. 71103120 \& 51507099) and Shanghai Social Science Planning General Project (Grant No 2018BG1019).

\section{Conflicts of Interest}

The authors declare no conflicts of interest regarding the publication of this paper.

\section{References}

[1] Chan, C.C. (2011) Outlook of Electric, Hybrid and Fuel Cell Vehicles. Journal of Automotive Safety \& Energy, 23, 507-516. (In Chinese)

[2] Bai, X. and Zhang, X. (2016) Review and 2017 Outlook of New Energy Vehicles Adoption. Journal of Beijing of Technology (Social Sciences Edition), 19, 39-44. (In Chinese)

[3] Ifeng Finance. How to Develop New Energy Vehicles and Their Charging Network. http://finance.ifeng.com/a/20150708/13827160_0.shtml

[4] Shen, M. (2015) Ten Trends of New Energy Vehicles in 2015. Science and Technology Daily. (In Chinese)

[5] Liu, Y.L. (2012) Research on the Construction of Beijing Pure Electric Vehicle Industry Chain. Beijing University of Technology, Beijing. (In Chinese)

[6] Yang, R.R. (2015) The Automobile Enterprises Are Facing "Internet plus" Change. Workers' Daily, 2015-3-25(8). (In Chinese)

[7] Han, G. (2015) Can the Internet Subvert the Traditional Automotive Industry? Heavy Truck, No. 5, 35-36. (In Chinese)

[8] Yi, M. (2014) The State Council Has Decided to Exempt the Purchase Tax of New Energy Vehicles. Equipment Manufacturing and Education, No. 28, 10. (In Chinese)

[9] Zhang, Y. (2017) Raise the Threshold of Subsidies, New Energy Vehicle Development Policy Is Boosted Again. China Business Journal, No. C09, 72-74. (In Chinese)

[10] Gong, M.Z. (2017) Subsidies for New Energy Vehicles Will Be Completely Abolished in 2020, and Experts said Subsidies Will Do More harm than Good. Securities Times, 2017-02-08. (In Chinese)

[11] Electronic Engineering World. How to Adjust the Pace of New Energy Vehicles under Pressure? http://www.eeworld.com.cn/qcdz/article_2017031617202.html

[12] Netease Finance. China's Rise in the Era of New Energy Vehicles. http://money.163.com/special/theme075

[13] Chen, X.G. (2014) China's Power Lithium Battery Industry Still Needs to Solve Many Difficulties. Energy Conservation \& Environmental Protection, No. 3, 48-49. (In Chinese)

[14] Yang, F. and Kong, F.F. (2014) Status and Development of Power Batteries for New Energy Vehicles. Shanghai Auto, No. 9, 3-8. (In Chinese) 
[15] Dong, B.Y. (2015) Development Status, Problems and Countermeasures of New Energy Vehicle Industry in China. Enterprise Economy, No. 3, 145-148. (In Chinese)

[16] Zhang, J.L., Ding, Z.D. and Yu, L. (2014) A Design of Intelligent Solar Charging Piles. Value Engineering, No. 35, 63-64. (In Chinese)

[17] Li, L. and Guo, Y. (2016) The Outstanding Problems of Charging Pile Construction and the Policies to Be Implemented Urgently. Energy of China, 38, 37-39. (In Chinese)

[18] Zhang, L. (2015) Superficial Analysis of the Major Technical Problems and Solutions of Electric Vehicles. Science and Technology \& Innovation, No. 21, 149-150. (In Chinese)

[19] China Intelligent Manufacturing Network. Further Analysis of How to Make a Breakthrough in the Development of New Energy Vehicles and Charging Pile Construction. http://www.gkzhan.com/news/detail/dy57183_p3.html

[20] Li, D.Y. (2011) Research on the Development of New Energy Automobile Industry under the Background of Low Carbon Economy in China. Economic Review, No. 2, 72-75.

[21] Zheng, C.Q. (2016) Study on Optimal Location of Charging Facilities for Urban Electric Vehicles. Nanchang University, Nanchang. (In Chinese)

[22] Dong, J.S. and Dong, Z.J. (2014) Study on Location Problem of Electric Vehicle Charging Station Considering Station Construction Cost. Forest Engineering, 30, 104-108.

[23] Gao, C.W. and Zhang, L. (2011) Review of the Impact of Electric Vehicle Charging on Power Grid. Power System Technology, 35, 127-131. (In Chinese)

[24] China Petroleum Information Center. Development Trend and Challenge of New Energy Vehicles in China. http://news.cnpc.com.cn/system/2015/01/21/001525716.shtml

[25] Wang, Y.H. and Miu, J. (2016) Research on Current Situation and Problems of Charging Piles. China Market, No. 41, 45-45. (In Chinese)

[26] Fang, L. (2013) Research on the Development Strategy of New Energy Vehicles Industry from the Perspective of Cost-Benefit Analysis in China. Central South University, Changsha. (In Chinese)

[27] Wang, H.Y. (2012) Research on the Development Strategy of New Energy Automotive Industry in China. Dongbei University of Finance and Economics, Liaoning. (In Chinese)

[28] Gao, M.Z. (2013) Research on New Energy Vehicles Industry in China. Jilin University, Changchun. (In Chinese)

[29] China Securities Journal Network. New Energy Vehicle Batteries Are Subject to Foreign Investment. http://auto.ce.cn/auto/gundong/201506/26/t20150626_5765269.shtml

[30] Wang, T.Y. (2014) Research on Battery Management System of Electric Vehicles. Anhui University of Science and Technology, Huainan. (In Chinese)

[31] Wang, L.Y. (2009) Key Technologies and Development Prospects of Electric Vehicles. Auto Industry Research, No. 8, 12-15. (In Chinese)

[32] Liu, Y., Wang, J. and Gong, L. (2016) Emissions of Chinese New Energy Vehicle and the Development Recommendations. Procedia Engineering, 137, 109-113. https://doi.org/10.1016/j.proeng.2016.01.240

[33] Zhang, W. (2015) Research on the Development Mode and Policy of New Energy Automotive Industry under the Background of Low Carbon Economy-Based on 
the Cases of BYD, Tesla and Toyota. Wuhan Textile University, Wuhan. (In Chinese)

[34] Wang, S.F. (2015) Research on Optimization of New Energy Vehicles Industry Chain in China. Donghua University, Shanghai. (In Chinese)

[35] Miao, Y. (2017) Key Work Plans for Developing New Energy Vehicles Industry. Auto Review, No. 2, 18-20. (In Chinese)

[36] Wu, H.M. (2014) Analysis of Present Situation and Prospects of New Energy Vehicles. Jilin University, Changchun. (In Chinese)

[37] Zheng, T.J. (2016) Current Situation and Prospect of Electric Vehicle Industry in China. China New Technologies and Products, No. 17, 137-139. (In Chinese)

[38] Yang, W.H., Chu, J.F. and Wu, Z. (2014) Calculation of Carbon Emission Reduction of New Energy Vehicles and Analysis of Its Influencing Factors. Environmental Engineering, No. 12, 148-152. (In Chinese)

[39] Liu, Z., Guo, W. and Wang, L. (2015) Development Analysis of New Energy Automobile Industry from the Perspective of Low Carbon. China Business Theory, No. 3, 132-134. (In Chinese)

[40] Tencent Automible. China Will Become the World's Largest Market for New Energy Vehicles. http://auto.qq.com/a/20140812/015509.htm

[41] Lan, Y.H. (2015) Research on the Development Trend of New Automotive Energy in China. Science and Technology Information, 13, 236-236.

[42] Xu, P.F. (2013) Research on the Path and Countermeasure of New Energy Vehicle Development in China. Zhejiang University of Technology, Hangzhou. (In Chinese)

[43] Wang, T. and Li, P. (2017) Research on Construction of New Energy Vehicle Charging Infrastructure Industry in China. Automotive Industry Research, No. 1, 4-9. (In Chinese)

[44] Sohu Network. Beijing New Energy Vehicle Company Cooperates with Yi Dao Company to Carry Out Government Vehicle Projects.

http://mt.sohu.com/20150703/n416138858.shtml

[45] China Quality Information Network. The First Internet Government Vehicle Platform Was Built in Jiangxi Province. http://www.cqn.com.cn/qt/content/2016-07/06/content_3111341.html

[46] China Electric Vehicle Network. The CEO of Yi Dao Was Selected as the Member of the Council of Electric Vehicles. http://www.zhev.com.cn/news/show-1434723072.html

[47] Li, H. (2015) The Development of Internet Car from "Yi Qi" Car. Automobile and Accessories, No. 16, 31-33.

[48] Shang, C. (2014) Market Promotion of New Energy Vehicles Accelerates the Golden Dragon Pure Electric Airport Ferry Service APEC. Commercial Automotive News, No. 45 , 14. (In Chinese)

[49] Lin, H. and Huang, Y.J. (2017) Preliminary Exploration of Investment and Operation Mode of Electric Vehicle Industry-Based on Electric Vehicle Charging Pile. China Business Trade, No. 12, 126-127. (In Chinese)

[50] Sohu Network. The Galaxy Electronic Company Opens "Internet plus" Times. http://stock.sohu.com/20150703/n416094952.shtml

[51] Zhang, C. (2016) Research on the Investment Opportunity of Charging Pile Caused by the Rapid Development of New Energy Vehicles. China Business Trade, No. 14, 142-143. (In Chinese) 
[52] Li, J. (2016) Introduction and Critical Technology Analysis of Internet of Vehicle. Telecommunications Science, 32, 34-38. (In Chinese)

[53] Liu, X.Y. and Wu, M.Y. (2012) Vehicle Networking: Application of Internet of Things in Urban Traffic Network. Journal of Computer Applications, 32, 900-904. (In Chinese) https://doi.org/10.3724/SP.J.1087.2012.00900

[54] Huang, Y.F. (2014) Project Planning Theory Research of New Energy Vehicle Product for Vehicle Manufacture Enterprise. South China University of Technology, Guangzhou. (In Chinese)

[55] Wang, X. and Zhang, D.H. (2014) New Energy Vehicles to Explore the Application of New Materials. Science and Technology \& Innovation, No. 16, 27-27. (In Chinese)

[56] Jiao, T.T. (2014) Design and Implementation of Electric Vehicle Charging Service Network Operation System. Electronic Production, No. 17, 160. (In Chinese)

[57] Ma, L. (2015) Research on Charging Facilities Construction of Electric Vehicles. North China Electric Power University, Beijing. (In Chinese)

[58] Yuan, X., Liu, X. and Zuo, J. (2015) The Development of New Energy Vehicles for a Sustainable Future: A Review. Renewable \& Sustainable Energy Reviews, 42, 298-305. https://doi.org/10.1016/j.rser.2014.10.016 